\title{
Considerations on the Hiring Process of Dentists in Brazilian Public Health Service and its Legal Repercussions
}

Considerações Sobre o Provimento do Cargo de Cirurgião-Dentista no SUS e suas Repercussões Legais

Carolina Burni Verçosa ${ }^{1}$, Mário Marques Fernandes ${ }^{1,2}$, Paulo Eduardo Miamoto Dias ${ }^{1}$, Mara Rosângeles de Oliveira ${ }^{2}$, Rodolfo Francisco Haltenhoff Melani ${ }^{3}$, Rogério Nogueira de Oliveira ${ }^{3}$

\begin{abstract}
It is important to comply with the administrative and regulatory requirements in hiring and provision of position for Dentists that underwent public admission examinations to operate on public health service. The activity provided by dental general practitioner or member of a Family Health Team-FHT is characterized by continuous and indispensable health services to the population. Therefore, it is recommended that these positions, whenever possible, be filled by public admission examinations. This paper aims to report a case of investigation by the Public Ministry with forensic dental counseling, in which aspects of provision of position and operation of Dentists of the FHT and general practitioners in the Brazilian public health system were compared, addressing the ethical and legal aspects inherent to the subject. In the case studied it was found that the functions performed by Dentists who work in the FHT and Basic Health Units are similar to each other, and that no technical requirements allowing one to differ them from another were noticed. It is emphasized that municipal managers must respect the legal principles concerning the provision of position for professionals to work in the public health service, under penalty of having their professional conducts investigated by the Public Ministry.
\end{abstract}

Key words: Oral Health, Unified Health System, Forensic Dentistry.

\section{Resumo}

Faz-se importante a observância das exigências administrativas e legais na contratação e nomeação de Cirurgiões-Dentistas (CDs) concursados para atuação no serviço público de saúde. A atividade prestada pelo $C D$ clínico geral ou integrante de uma Equipe de Saúde da Família (ESF) é caracterizada, fundamentalmente, pelo atendimento contínuo à população, recomendando-se que, salvo de situações de exceção, os profissionais devem ser escolhidos por concurso público. Este trabalho objetivou relatar um caso de investigação realizada pelo Ministério Público (MP) com assessoramento odontolegal, onde se comparou aspectos da nomeação e atuação de CDs da ESF e CDs clínicos-gerais no SUS, abordando os aspectos éticos e legais inerentes ao tema. Apurou-se que as funções desempenhadas pelos cirurgiões-dentistas que trabalham nas ESF e nas Unidades Básicas de Saúde (SUS), no caso estudado, são semelhantes entre si, sendo que não se observaram requisitos técnicos diferenciadores entre as atividades. Ressalta-se que os gestores municipais devem respeitar os princípios legais que regem a nomeação destes profissionais para atuarem em serviço público de saúde, sob pena de serem investigados pelo MP em suas condutas.

Palavras-chave: Saúde bucal, Sistema Único de Saúde, Odontologia Legal.
${ }^{1}$ Doutorando(a) em Odontologia Legal, Departamento de Odontologia Social, FOUSP, Brasil.

${ }^{2}$ Serviço Biomédico do Ministério Público, Rio Grande do Sul, Brasil.

${ }^{3}$ Professor Doutor, Departamento de Odontologia Social, FOUSP, Brasil.

Correspondência: Rogério Nogueira de Oliveira

Endereço: Avenida Professor Lineu Prestes, 2227, Cidade Universitária.

05508000 - São Paulo/SP - Brasil

E-mail: rogerion@usp.br

Data de Submissão: 03/07/2013

Data de Aceite: 29/10/2013

\section{Introduction}

The provision of job positions as Dentists in the public health service must comply with legal and administrative requirements of all cities assisted by those professional. Otherwise, those responsible may be investigated by Public Ministry for their conducts. Activities in health centers and those performed as a member of the Family Health Team (FHT) of the Family Health Program (FHP) are among the possible acting fields of Dentists admitted in public service (BRASIL, 1998, 2004).

The clinical performance of the Dentists at public service, serving the population, has a permanent and essential characteristic. Thus, such positions, called effective provision positions, must necessarily be filled by public hiring processes for both general practitioners or members of the local FHT (BRASIL, 1998).

Failure to comply with these legal and administrative aspects in the process of nomination of dental professionals to act in the public service may incur administrative misconduct. Such cases are subject to the intervention of the Public Ministry, by a civil investigation, watching over the effective functioning of the services provided to the population.

This paper aims to report a case of investigation conducted by the Public Ministry with forensic dental advice, where it was compared aspects of the nomination and performance of FHS and general practitioner Dentists in the public dental services, addressing the ethical and legal issues inherent in the admission regulations for its staff.

To constitute a gateway to the health system, the core network (including the Family Health Units) must be inserted into a functional and resolute system with hierarchical service networks. It is necessary to work with a scientific-technological apparatus able to solve about $80 \%$ of the health problems of the population (CAMPOS, 2003).

A major challenge of the Family Health Strategy is related to its ability to integrate with the rest of the public health system in order to qualitatively redefine the model health care. The individual curative care health care model keeps perpetuating because there is not an uniform performance of the FHTs (RONZANI; STRALEN, 2003).

According to the Ministry of Health, the Oral Health Teams $(\mathrm{OHT})$ must aim to: ensuring access of all families living in areas covered by the FHTs to health promotion actions, orient oral health 
care practices according to the strategies recommended by the Family Health Strategy, continuously train and educate oral health professionals, through articulation between higher education institutions and the actions of the public health service and evaluate the quality and impact of oral health actions developed (BRASIL, 2004).

With the inclusion of Oral Health in the Family Health Strategy, the job market has opened up to Dentists, where one can see the importance of the hiring process of professionals to work in the program, as well as the workload and wage conditions. According to the Ministry of Health, the selection of professionals for the FHT must be done by internal selective process, public hiring process or external recruitment by regular hiring complying the dispositions Consolidation of Labor Laws (CLT). However, what is mostly observed is hiring of Dentists for temporary positions or provision of services (LOURENÇO et al., 2009).

The ordinance 648/GM (BRASIL, 2006a) states that the Family Health Team (FHT) is responsible for no more than 4000 inhabitants and recommends the average of 3000 . Regarding the OHTs, they can integrate up to two FHTs.

The legal nature of commissioned positions, differentiating them from providing effective positions is exposed by Meirelles (1994):

"The effective endowment is inherent to positions of the permanent staff of the Administration, filled by the great mass of functionalism, with initial provision by public hiring process, for the performance of technical and administrative activities of the State, with the character of professional practice. Conversely, the comissioned endowment is appropriate for public officials of high rank, called to provide services to the State, without professional character, and of even honorary and transitory nature."

About the positions of commissioned provision, Gasparini (2002) explains that:

"the provision in commissioned positions are fit for the direction, control or management of certain organs, where an agent needs to be of confidence of the appointing authority and willing to follow their lead, helping to promote the higher management of administration. "

From such concepts, it appears that the commissioned positions comprises four features: 1) the exceptionality, 2) leadership, 3) confidence and 4) free nomination and dismissal.

The article 155 of the Brazilian Civil Code (BRASIL, 2002) provides that procedural acts are public, except for those pertaining to marriage, paternity, spousal separation, conversion to divorce and custody of children.

Resolution 23/2007 of the National Council of the Public Ministry (BRASIL, 2007), article seven, paragraph two, states that the principle of publicity of acts applies to civil investigation, by means specified in items I to $\mathrm{V}$ (such as the official release in the cybernetic or electronic media, dispatch of certificates and extraction of documental copies about facts investigated and providing information to the general public).

Since the promulgation of the 1998 Constitution, the Public Ministry is essential to the Justice, highlighting its role in protection of collective and individual interests (BRASIL, 1998). The bureau acts in several cases, including the repression of acts of misconduct involving public officials dealing with funds allocated to public health (FERNANDES et al., 2011), investigation of complaints by animal protective organization in which a researcher would be supposedly mistreating dogs in implantology experiments (DIAS et al., 2010), among other requests. Investigations are carried out to verify irregularities related to advertising in Dentistry (FERNANDES et al., 2012). Irregularities in a Public Health Unit were also verified, where poor sanitary conditions and failure to comply with technical standards were brought to the Public Prosecutor (FERNANDES et al., 2018).

\section{Case Report}

The study was conducted through literature review and analysis of a case report involving a civil investigation that sought to ascertain the legality of hiring dentists to work in the public health service by a municipality of a city in southern Brazil. The municipal government hired a company through bidding to perform this task.

In the present case, a public hiring process was promoted to admit one dentist to work in the Family Health Team of the municipality, in a position of permanent character. However other three Dentists were hired (the third place of the public hiring process and two other professionals who did not even take the test) in character provisioned commission. The second place at the public hiring process filed a complaint to the Public Ministry, who started a civil investigation.

In diligence, it was found that a municipal law ensured the hiring of three Dentists in character provisioned commission to work at the local public health center. It was also found that three Dentists worked on the site: one gazetted (workload of 40 hours per week) approved in the first place in the public hiring process described above, working as station chief, and two other hired professionals (workload of 20 hours per week).

After searching in the National Register of Health Service Establishments (CNES), it was found that there were four dentists registered.

Seeking to investigate possible differences between the duties performed by the public employees and the ones contracted in commissioned provision, Public Ministry requested a Technical Advisory Opinion to its state Biomedical Department to assist investigations.

After analysis of the existing documents in the investigation, dental professionals of the Biomedical Service of the Public Ministry concluded that: the functions performed by both categories of professionals are similar to each other; there seems to be no technical requirements differentiating between activities; and still, that in accordance with the recommendations of the Family Health Program, only one CD (in case the first gazetted) integrating a FHT would be enough to assist the average number of patients recommended by the Program, which is a maximum of 4000 inhabitants or a recommended average of 3000 patients. The municipality had 2,916 inhabitants at the time of the investigations.

It was also found that all professionals used is the same system to inform their professional production (SIA / SUS) (BRASIL, 2006b).

Given the observed facts, the filed charges to the Judicial Authority, requiring validity of consequent Public Civil Action, so that the legal principles guiding the hiring of Dentists to act in the public health service may be complied with.

This study was approved by the Ethics Committee in Research of the Faculty of Dentistry, University of São Paulo under number CAAE 0075.0.017.000-11.

\section{Discussion}

Due to the increase in vacancies and improvement in working conditions in the last recent years, the public sector has become an important employment niche for the dental category.

According to the Ministry of Health, the workload of a dentist should be 40 hours per week and the average attendance for each OHT must be 6,900 patients, considering the proportion of one for two active FHTs. In municipalities with less than 6,900 inhabitants, the

Rev. Fac. Odontol. Porto Alegre, v. 53, n. 3, p. 18-20, set./dez., 2012. 
OHT can be deployed to one or two FHTs (BRASIL, 2004).

In the present case, the conduct of Dentists hired in provisioned commission was not in accordance to the Ministry of Health's guidelines (BRASIL, 2004), since both had a workload of 20 hours per week, while the Dentist admitted in public hiring process worked for 40 hours, as reccomended. This reinforces the idea that the public hiring process is the democratic way of hiring public workers on equal terms.

The Federal Constitution of Brazil (BRASIL, 1998), clearly states the rules for the admission in the public service, pointing out that the endowment in a public position depends on the approval in a public hiring process, in agreement to the nature and complexity of the position. Thus, it directly and indirectly enforces the public administration, in any of the Powers of the Union to compliy with the principles of legality, impersonality, morality, publicity and efficiency.

The Public Ministry (BRASIL, 1998) considers unconstitutional all ways of entering the public service through private arrangements, as seen in the case reported and pointed out in the requested Technical Advisory Opinion. The role of the private sector in providing services to the public health system is merely accessory and can not characterize the transfer of health service to a private person or institution. Besides the uncostitutional entry of the denounced Denstists, the Technical Advisory Opinion report points to a demand for care that could be supplied only by dentist, hired on a public contest.

With the technical advice performed by Dentists of the Public Ministry, it was possible to refer to the competent agency all the bases for filing a civil lawsuit, with the prerogative to defend the collective interest.

\section{Conclusion}

It was found that the functions performed by Dentists working in the FHT and the Basic Health Units in the case reported are similar to each other with no noticeable technical requirements differentiating between activities. It is emphasized that municipal managers must respect the legal principles governing the admittance of professionals to work in the public health service, under penalty of being investigated by the Public Ministry on their conducts.

\section{Acknowledgments}

Authors thank the Attorney-General for Administrative Affairs of the Public Ministry of Rio Grande do Sul for permission to publish the case, preserving the identity of those involved.

\section{References}

BRASIL. Constituição da República Federativa do Brasil de 05 de dezembro de 1998.

BRASIL. Código Civil. Lei n 10.406, de 10 de Janeiro, 2002.

BRASIL. Ministério da Saúde. Secretaria de Atenção à Saúde. Departamento de Atenção Básica. Coordenação Nacional de Saúde Bucal. Diretrizes da Política Nacional de Saúde Bucal, 2004.

BRASIL. Ministério da Saúde. Portaria n 648/GM, de 28 de março, 2006a.

BRASIL. Ministério da Saúde. Secretaria de Atenção à Saúde. Departamento de Atenção Básica - Saúde Bucal. Cadernos de Atenção Básica - $\mathrm{n}^{\circ}$ 17, 2006b.

BRASIL. Conselho Nacional do Ministério Público. Resolução $\mathbf{n}^{\circ} \mathbf{2 3}$ de 17 de setembro de 2007.
CAMPOS, G. W. S. Saúde paidéia. São Paulo: Hucitec; 2003.

DIAS, P. E. M.; FERNANDES, M. M,; OLIVIERA, M. R.; OLIVEIRA, R. B. C. M.; DARUGE Jr., E.; MELANI, R. F. H. Denúncia de maus tratos em animais relacionada à pesquisa odontológica. Odontologia e Sociedade, v. 12, n. 2, p. 01-06, 2010.

FERNANDES, M. M.; OLIVEIRA, R. B. C. M.; SCORALICK, R. A.; BARBIERI, A. A.; DARUGE Jr., E. Atuação do Ministério Público na biossegurança de consultório odontológico da rede pública. Boletim da Saúde, v. 22, n. 2, p. 133-138, 2008.

FERNANDES, M. M; OLIVEIRA, M. R.; BRAGANÇA, D. P.; SILVA, R. F; DARUGE Jr., E. Relato de investigação relacionada ao financiamento de ortodontia pela rede pública. Odonto, v. 19, n. 37 , p. 49-53, 2011.

FERNANDES, M. M; OLIVEIRA, M. R.; OLIVEIRA, O. F.; PARANHOS, L. R.; DARUGE Jr., E. Veiculação de publicidade irregular relacionada a um cartão de descontos em odontologia: relato de caso. Revista da Faculdade de Odontologia - UPF, v. 17, n. 1, p. 86-90, 2012.

GASPARINI, D. Direito Administrativo. São Paulo: Saraiva; 2002.

LOURENÇO, E. C.; SILVA, A. C. B.; MANEGHIN, M. C.; PEREIRA, A. C. A inserção de equipes de saúde bucal no Programa Saúde da Família no Estado de Minas Gerais. Ciência \& Saúde Coletiva, v. 14, n. 1, p. 1367-1377, 2009.

MEIRELLES, H. L. Direito Administrativo Brasileiro. São Paulo: Malheiros; 1994.

RONZANI, T. M.; STRALEN, C. J. Dificuldades de implantação do Programa Saúde da Família como estratégia de reforma do sistema de saúde brasileiro. Revista de Atenção Primária à Saúde, v. 6, p. 7-22, 2003. 